\title{
Editorial Comment: External validation of nomogram to predict inguinal lymph node metastasis in patients with penile cancer and clinically negative lymph nodes
}

\author{
Luciano A. Favorito 1, 2, 3 \\ ${ }^{1}$ Professor Titular, Unidade Urogenital da Univ. Est. do Rio de Janeiro - UERJ, RJ, Brasil; ${ }^{2}$ Urologista do \\ Hospital da Lagoa Federal, Rio de Janeiro , RJ, Brasil; 3 Editor Associado do International Braz J Urol
}

In this interesting paper Dr. Maciel and collegues from Sao Paulo - Brazil conduct an external validation of a previously developed nomogram (1) to predict inguinal lymph node (ILN) metastases in penile cancer in patients with clinically negative lymph nodes. The authors analyzed 65 men with penile cancer who underwent inguinal lymph node dissection. Of 65 men, only 24 (36.9\%) presented with positive LNs. The authors concluded that the present nomogram applied in Brazilian population had low accuracy and low precision for correctly identifying patients with penile cancer who have positive ILN.

Penile cancer is a rare neoplasia with low incidence in developed countries. In Brazil the incidence rate of penile cancer is $2.9-6.8 / 100,000$ inhabitants, resulting in this country having one of the world's highest incidence rates for this neoplasia (2-4). The most common sites of penile cancer metastasis are the superficial and deeper nodes of the inguinal and iliac region. The occurrence and extent of inguinal lymphatic metastasis are the most important prognostic factors in patients with penile cancer and usually imply worse oncologic prognosis (5). Extended Inguinal lymphadenectomy (open, laparoscopic or robotic) is the most useful and commonly performed surgery for staging and to cure inguinal metastasis in penile cancer cases. Although it is a widespread technique, post operatory complications often occur (6-8).

This paper is very important, but in the future, papers with prospective studies and with a more significant sample will be necessary to confirm the application of this nomogram to predict inguinal lymphatic metastasis in patients with penile cancer.

\section{REFERENCES}

1. Maciel CVM, Machado RD, Morini MA, Mattos PAL, Dos Reis R, Dos Reis RB, et al. External validation of nomogram to predict inguinal lymph node metastasis in patients with penile cancer and clinically negative lymph nodes. Int Braz J Urol. 2019;45:671-8.

2. Zhu Y, Zhang HL, Yao XD, Zhang SL, Dai B, Shen YJ, Ye DW. Development and evaluation of a nomogram to predict inguinal lymph node metastasis in patients with penile cancer and clinically negative lymph nodes. J Urol. 2010;184:539-45.
3. Favorito LA, Nardi AC, Ronalsa M, Zequi SC, Sampaio FJ, Glina S. Epidemiologic study on penile cancer in Brazil. Int Braz J Urol. 2008;34:587-91; discussion 591-3.

4. Pizzocaro G, Algaba F, Horenblas S, Solsona E, Tana S, Van Der Poel $\mathrm{H}$, Watkin NA; European Association of Urology (EAU) Guidelines Group on Penile Cancer. EAU penile cancer guidelines 2009. Eur Urol. 2010 Jun;57(6):1002-12.

5. Culkin DJ, Beer TM. Advanced penile carcinoma. J Urol. 2003;1702Pt1):359-65.

6. Chiapparrone G, Rapisarda S, de Concilio B, Zeccolini G, Antoniutti M, Celia A. Saphenous-sparing laparoscopic inguinal lymphadenectomy. Int Braz J Urol. 2018;44:645-6. 
7. Meneses AD, Mattos PAL, Eulálio WMN Filho, Fé TSM, Rodrigues RMM, et al. Initial experience of video endoscopic inguinal Lymphadenectomy in a center located at northeast brazilian region. Int Braz J Urol. 2019;45:325-31.

8. Favorito LA. The future of inguinal Lymphadenecotmy in penile cancer: laparoscopic or robotic? Int Braz J Urol. 2019;45:208-9.

ARTICLE INFO

Luciano A. Favorito http://orcid.org/0000-0003-1562-6068

Int Braz J Urol. 2019; 45: 679-80

Correspondence address:

Submitted for publication: May 05, 2019

Luciano Alves Favorito, MD, PhD

Accepted after revision:

Rua Professor Gabizo, 104 / 201

May 06, 2019

Tijuca, Rio de Janeiro, 20271-320, Brasil

Fax: +55 21 3872-8802

E-mail: lufavorito@yahoo.com.br

Published as Ahead of Print:

June 10, 2019 